\title{
Nutrient acquisition and eucalyptus growth affected by humic acid sources and concentrations
}

\section{Aquisição de nutrientes e crescimento do eucalipto sob efeito de fontes e concentrações de ácido húmico}

\author{
Everton Geraldo de Morais $^{1 *}$; Carlos Alberto Silva ${ }^{2}$; Sara Dantas Rosa ${ }^{1}$
}

\begin{abstract}
Humic acid (HA) can increase eucalyptus growth due to its biostimulant effect and improvement in plant nutrient uptake. Magnitude of these stimuli varies according to the source, chemical composition, presence of bioactive fragments, and concentration of HA. The aim of this study was to evaluate the effect of HA sources and concentrations on dry matter, accumulation and uptake efficiency (UpE) of nutrients for eucalyptus seedlings cultivated in nutrient solution. A randomized block experimental design was adopted, with four replications, in a $3 \times 4+1$ factorial scheme, in which three sources of HA (HA-L1 and HA-L2, derived from different commercial HA extracted from leonardite with $0.5 \mathrm{~mol} \mathrm{~L}^{-1}$ $\mathrm{NaOH}$ and $0.5 \mathrm{~mol} \mathrm{~L}^{-1} \mathrm{KOH}$, respectively, and HA-Com, which was extracted from compost with 0.5 mol L-1 KOH) were combined with four concentrations of C-HA $\left(5,10,25\right.$, and $\left.100 \mathrm{mg} \mathrm{L}^{-1}\right)$ as well as a control treatment in which eucalyptus was cultivated without HA. Eucalyptus seedlings were grown for 20 days, maintaining three plants per pot. At the end of the experiment, production of shoot dry matter (SDM), root dry matter (RDM), and total dry matter (TDM); the Root: Shoot dry matter ratio; and the accumulations of $\mathrm{N}, \mathrm{P}, \mathrm{K}, \mathrm{Ca}, \mathrm{B}, \mathrm{Cu}, \mathrm{Fe}$, and $\mathrm{Zn}$ in the shoot and root were evaluated as well as the $\mathrm{UpE}$ of these nutrients by the seedlings. Maximum production of SDM was reached at the concentrations of 14 and $13.5 \mathrm{mg} \mathrm{L}^{-1}$ of C-HA, for HA-L1 and HA-Com, respectively. The RDM increased with the use of HA-Com, with optimal concentration of $55 \mathrm{mg} \mathrm{L}^{-1}$ of C-HA. Accumulation of Fe in the eucalyptus shoot decreased in HA-treated pots, compromising Fe translocation from the root to the shoot. Regardless of HA source used, $\mathrm{Cu}$ accumulation by plants diminishes as $\mathrm{C}-\mathrm{HA}$ concentration increases. A greater growth of eucalyptus at concentrations lower than $15 \mathrm{mg} \mathrm{L}^{-1}$ of C-HA occurs more through the stimulus to shoot and root growth than due to greater acquisition and $\mathrm{UpE}$ of nutrients by plants. Use of high concentrations of $\mathrm{C}$-HA requires greater concentration of some micronutrients in the nutrient solution tested.
\end{abstract}

Key words: Nutrient uptake. Bioactivity of humic fragments. Organic-metallic complexes. Uptake efficiency of nutrients. Humic substances.

\section{Resumo}

$\mathrm{O}$ ácido húmico $(\mathrm{AH})$ pode aumentar o crescimento do eucalipto devido a seu efeito bioestimulante e aumento da absorção de nutrientes pelas plantas. A magnitude desses estímulos varia conforme a fonte, composição química, presença de fragmentos bioativos e concentração de AH. Objetivouse, assim, avaliar o efeito de fontes e concentrações de AH na massa seca, aquisição e eficiência de absorção (EAbs) de nutrientes por mudas de eucalipto cultivadas em solução nutritiva. O experimento

1 Discentes de Doutorado, Departamento de Ciência do Solo, Universidade Federal de Lavras, UFLA, Lavras, MG, Brasil. E-mail: evertonmoraislp@yahoo.com.br; saradantasrosa@gmail.com

2 Prof. Titular, Departamento de Ciência do Solo, UFLA, Lavras, MG, Brasil. E-mail: csilva@dcs.ufla.br

* Author for correspondence 
foi realizado em delineamento de blocos casualizados, com quatro repetições, em esquema fatorial $3 \times 4+1$, sendo testadas três fontes de AH (AH-L1 e AH-L2, derivados de diferentes produtos comerciais de $\mathrm{AH}$, tendo como material de extração leonardita, sendo extraídos com $\mathrm{NaOH} 0,5 \mathrm{~mol} \mathrm{~L}^{-1}$ e $\mathrm{KOH}$

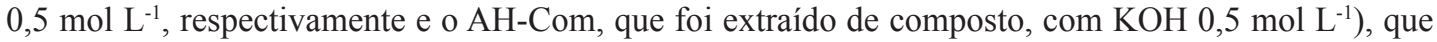
foram combinadas com quatro concentrações de C-AH $\left(5,10,25\right.$ e $\left.100 \mathrm{mg} \mathrm{L}^{-1}\right)$, além de um tratamento controle onde o cultivo do eucalipto foi feito sem aplicação de AH. Mudas de eucalipto foram cultivadas durante 20 dias, mantendo-se três plantas por vaso. Ao final do experimento, foram avaliados a produção de massa seca da parte aérea (MSPA), raiz (MSR) e total (MST), relação de massa seca raiz/parte aérea e os acúmulos de N, P, K, Ca, B, Cu, Fe e Zn na parte aérea e raiz, além da EAbs desses nutrientes pelas mudas de eucalipto. Há máxima produção de MSPA para concentrações de 14 e 13,5 mg L-1 de C-AH, respectivamente, para AH-L1 e AH-Com. A MSR aumentou com o uso de AH de composto, sendo máximo o crescimento de raiz para a concentração de $55 \mathrm{mg} \mathrm{L}^{-1}$ de $\mathrm{C}-\mathrm{AH}$. O acúmulo de Fe na parte aérea do eucalipto diminuiu com a aplicação de $\mathrm{AH}$, comprometendo a translocação do nutriente da raiz para a parte aérea. Há restrição severa no acúmulo de $\mathrm{Cu}$ pelas plantas à medida que se aumenta a concentração de $\mathrm{C}-\mathrm{AH}$, independentemente da fonte de $\mathrm{AH}$ utilizada. O maior crescimento do eucalipto em concentrações menores que $15 \mathrm{mg} \mathrm{L}^{-1}$ de C-AH ocorre mais pelo estímulo ao crescimento da parte aérea e de raízes do que devido à maior aquisição e EAbs de nutrientes pelas plantas. $\mathrm{O}$ uso de altas concentrações de C-AH demanda maior concentração de alguns micronutrientes na solução nutritiva. Palavras-chave: Absorção de nutrientes. Bioatividade de fragmentos húmicos. Complexos orgânicosmetálicos. Eficiência de absorção de nutrientes. Substâncias húmicas.

\section{Introduction}

Humic acid (HA) is currently classified as supramolecular organic structures that have relatively high molecular weight, in the range of 50,000 to 100,000 Daltons (STEVENSON, 1994). Supramolecular humic structures are due to associations of relatively small and heterogeneous humic fragments held together by low energy bonds (PICCOLO, 2001). The effect of HA application on plants has recently been researched and has shown high potential for use (BALDOTTO et al., 2016; ROSE et al., 2014). Humic acid action occurs through direct action on plants, or indirectly, due to HA changes in the growth media, affecting nutrient acquisition and plant growth (LYONS; GENC, 2016). HA direct action on plants includes an effect similar to the role played by auxins on plants (DOBBSS et al., 2010; NARDI et al., 2016). Besides, HA increases number of physiologically active root (RIMA et al., 2011), and improves the plasmatic membrane $\mathrm{H}^{+}$-ATPase activity (NARDI et al., 2016). In addition, HA can stimulate nutrient transporter activity (JINDO et al., 2016; TAVARES et al., 2017; TOMASI et al., 2014). Indirect effects are those associated with the ability of HA to change the growth medium $\mathrm{pH}$ and electrical conductivity (EC) and nutrient complexation, changing macro and micro nutrients availability (LYONS; GENC, 2016; PINHEIRO et al., 2010). These effects on nutrient acquisition are controlled by HA source and concentration (ROSE et al., 2014).

Humic acid can be obtained from different sources, such as peat, leonardite, lignite, and composts, and from humified urban residues, such as sewage sludge and composted garbage (ROSE et al., 2014). All these HA sources include materials that are differentiated in regard their chemical composition, fractions molecular weight, and bioactivity of humic fragments contained in HA matrix, which makes it difficult to foresee the agronomic efficiency as well as comparisons of the action mechanisms of different HA sources (GARCÍA et al., 2016; LYONS; GENC, 2016; ROSE et al., 2014). The structure, chemical composition, and quantity and types of functional groupings in the HA structure are key factors to establish the relationship between the chemical and physicochemical nature of the HA and its effects on plants (GARCÍA et al., 2016). According to Rose et al. (2014), the source of HA modulates its effect on 
plants by changing $\mathrm{pH}, \mathrm{EC}$, nutrient concentrations, presence of organic acids, molecular weight, presence of hormones, and other substances that play an important role in plant physiological and biochemical processes, mainly those HA derived from composted sources (MARTINEZ-BALMORI et al., 2014; ROSE et al., 2014). The effect of the HA source is dependent on the concentration used, which affects nutrient acquisition by plants (AZCONA et al., 2011), considered that compostderived HA are more chemically bioactive and requires lower optimal concentrations to positively affect plants (GARCÍA et al., 2016; ROSE et al., 2014).

The range of HA optimal concentrations that ensure greater growth and accumulation of nutrients in diverse plant species is from 5 to $300 \mathrm{mg} \mathrm{L}^{-1}$ of HA (CHEN; AVIAD, 1990), when including experiments with plant cultivation of plants in growth media with varied capacity to buffer, $\mathrm{pH}$, nutrients availability etc. According to Pinheiro et al. (2010), for the eucalyptus seedlings growth in nutrient solution, the optimal HA concentration is around $5 \mathrm{mg} \mathrm{L}^{-1} \mathrm{C}-\mathrm{HA}$. The optimal concentrations of HA for optimum plant growth in nutrient solution are lower compared to those rates required by plants cultivated in soils. Nevertheless, in both situations, the responses in plant growth are normally explained by the quadratic mathematical models in which there is an increase up to an optimal HA concentration, followed by a decrease after that rate (ROSE et al., 2014). HA sources and concentrations interact with the plant species, controlling the magnitude of HA effect on plant growth and nutrition acquisition; the plant species is the main factor that modulates the response to HA application (AGUIAR et al., 2009; ROSE et al., 2014). Grasses and leguminous are more responsive to HA application than woody plants (ROSE et al., 2014). The potential response of perennial crops do HA application is low; however, this affirmation is not conclusive, due to the small number of studies that evaluate HA application effects on woody plants (ROSE et al., 2014), especially for crops with high economic relevance for Brazil such as eucalyptus.

The positive effect of HA can be either through increased plant growth and greater uptake of nutrients or due to greater efficiency in nutrient acquisition (BILLARD et al., 2014). Due to the difference between sources of HA currently available, many aspects still need to be clarified, especially the optimal concentration of HA, which is specific for each source of HA used (ROSE et al., 2014). HA can decrease (PINHEIRO et al., 2010), increase (CANELLAS et al., 2015; EKINCI et al., 2015; MELO et al., 2015; NARDI et al., 2016), or even not change nutrient uptake by crops, depending on the conditions and characteristics of the growth medium where the plants are grown. According to Pinheiro et al. (2010), increase in HA concentration in nutrient solution drastically reduced accumulation of $\mathrm{Fe}, \mathrm{Cu}$, and $\mathrm{Zn}$; however, for $\mathrm{Mn}$, this effect was not so pronounced as for $\mathrm{Fe}, \mathrm{Cu}, \mathrm{Zn}$ and $\mathrm{B}$; depending on the source, $\mathrm{Mn}$ accumulation improves when the concentration of $10 \mathrm{mg} \mathrm{L}^{-1} \mathrm{C}-\mathrm{HA}$ is used. Application of HA increasing macronutrient accumulation in plants is shown in greater magnitude for $\mathrm{N}, \mathrm{P}, \mathrm{K}$, and $\mathrm{Ca}$ (AZCONA et al., 2011; EKINCI et al., 2015; MELO et al. 2015; TAVARES et al., 2017), whereas, for $S$ and $\mathrm{Mg}$, this effect may be small or null (AZCONA et al., 2011; PINHEIRO et al., 2010).

As the effect of HA may be related to the influence of the humic material on physicochemical aspects of the growth medium, as was reports by soil (ROSE et al., 2014), cultivation in nutrient solution allows the study of direct effect of HA on growth and on nutrient acquisition by plants. However, since nutrient solution is a medium that is not highly buffered, the HA can form complexes with nutrients of lower availability, especially with metals, which would affect their acquisition by plants (PINHEIRO et al., 2010). The main factor that controls the bioavailability of the complexes formed between nutrients and HA is their chemical stability (BOGUTA; SOKOŁOWSKA, 2016; NUZZO et 
al., 2013). Tomasi et al. (2014), in cucumber plants, verified an increase in acquisition of $\mathrm{Fe}$ combined with humic fractions extracted in water. However, this HA bonding with metals might not be as stable as is the case for some $\mathrm{Cu}$ and $\mathrm{Fe}$ organometallic complexes (OMCs), considering high energy bonds that are established between the organic ligand and metals, which results in complexes of high chemical stability (NUZZO et al., 2013; XU et al., 2016), decreasing their acquisition by plants.

In this context, we hypothesized that: (i) The HA extracted from compost is more effective in increasing biomass production and accumulation of nutrients than HA extracted from leonardite. (ii) There is an optimal concentration of HA for optimum growth of eucalyptus, and those concentrations over the ideal threshold limit decrease eucalyptus dry matter due to the low efficiency of plants in taking up $\mathrm{Cu}$ and $\mathrm{Fe}$ in an environment with a strong offer of organic ligands that immobilize these metals. (iii) The increase in nutrient acquisition is more related to greater production of biomass and plant growth than to an increase in efficiency of eucalyptus in using nutrients. Thus, the aim of this study was to evaluate the effect of increasing concentrations of HA from leonardite and from compost on the nutrient acquisition and growth of eucalyptus seedlings grown in nutrient solution.

\section{Materials and Methods}

The experiment was carried out in greenhouse conditions at the Soil Organic Matter Research Laboratory of the Federal University of Lavras, Lavras, MG, Brazil, at $21^{\circ} 13^{\prime} 35^{\prime \prime} \mathrm{S}$ and $44^{\circ}$ 58 ' 46 "'W and $900 \mathrm{~m}$. AMSL. The region has a mean annual temperature of $19-20{ }^{\circ} \mathrm{C}$ and mean annual rainfall of $1486 \mathrm{~mm}$. Eucalyptus clones of the hybrid VM 01 (Eucalyptus urophylla x Eucalyptus camaldulensis) were grown in nutrient solution. One and three months eucalyptus clones old were acquired from a commercial nursery located in Nepomuceno municipality, MG state, Brazil; on average, the plant height was $30 \mathrm{~cm}$. Three sources of HA were used: HA-L1 and HA-L2, derived from different commercial HA products, since they were extracted from leonardite with $0.5 \mathrm{~mol} \mathrm{~L}^{-1}$ $\mathrm{NaOH}$ and $0.5 \mathrm{~mol} \mathrm{~L}^{-1} \mathrm{KOH}$, respectively. The HACom was extracted from a 150-day incubated and humified compost. The compost used for extraction of HA was formulated according to the conditions described in Silva (2008), using 60\% (v/v) coffee husk, 30\% chicken manure, and 10\% biochar. After composting, the compost was dried, ground and characterized following the analytical protocols described in Higashikawa et al. (2010). Nutrient contents in the composts were: $315,16.4,15.5,3.5$, $49.2,3.1,5.0,0.44,0.31$, and $1.55 \mathrm{~g} \mathrm{~kg}^{-1}$ of $\mathrm{C}, \mathrm{N}$, $\mathrm{P}, \mathrm{K}, \mathrm{Ca}, \mathrm{Mg}, \mathrm{Fe}, \mathrm{Mn}, \mathrm{Zn}$, and $\mathrm{Na}$, respectively, as well as $4.0,27.7$, and $60.3 \mathrm{mg} \mathrm{kg}^{-1}$ of $\mathrm{S}, \mathrm{B}$, and $\mathrm{Cu}$, respectively.

The compost-derived HA was extracted using $0.5 \mathrm{~mol} \mathrm{~L}^{-1} \mathrm{KOH}$ solution, according to the protocol recommended by the International Humic Substances Society, described by Swift (1996). HAs were characterized regarding their elemental chemical composition (Table 1). Humic acids were analyzed in an attenuated total reflectance Fourier transform infrared (ATR-FTIR) machine, and the spectra were generated considering the distribution of chemical groups in the mid-infrared spectral region of 4000 to $800 \mathrm{~cm}^{-1}$, using a $2 \mathrm{~cm}^{-1}$ resolution (Figure 1). The main chemical groups present in the humic matrix were identified according to the infrared (IR) spectral signature library described in Stevenson (1994). 
Table 1. Chemical composition of the humic acids (HAs) used in the experiment.

\begin{tabular}{|c|c|c|c|c|c|c|c|c|c|c|c|c|}
\hline HA & $\mathrm{C}$ & $\mathrm{N}$ & $\mathrm{P}$ & $\mathrm{K}$ & $\mathrm{Ca}$ & $S$ & $\mathrm{Na}$ & $\mathrm{Fe}$ & B & $\mathrm{Cu}$ & $\mathrm{Mn}$ & $\mathrm{Zn}$ \\
\hline L-1 & 332,8 & 7,5 & 0,21 & 3,9 & 5,6 & 4,5 & 71,4 & 11,9 & 12,5 & 45,7 & 18,9 & 25,3 \\
\hline Com & 251,9 & 29,0 & 4,70 & 36,1 & 1,4 & 6,3 & 1,6 & 1,8 & 6,5 & 181,7 & 31,8 & 80,9 \\
\hline L-2 & 354,9 & 5,3 & 0,05 & 41,6 & 1,4 & 2,8 & 3,2 & 2,7 & 41,6 & 7,6 & 21 & 76,3 \\
\hline
\end{tabular}

L1: HA extracted from Leonardite with $\mathrm{NaOH}$; Com: HA extracted from organic compost with $\mathrm{KOH}$; L2: HA extracted from Leonardite with $\mathrm{KOH}$.

Figure 1. ATR-FTIR spectrum of the humic acid (HA) samples and the main organic chemical groups assignments found in humified matrices. HA-L1: HA extracted from Leonardite with $\mathrm{NaOH}$; HA-Com: HA extracted from organic compost with $\mathrm{KOH}$; HA-L2: HA extracted from Leonardite with $\mathrm{KOH}$.

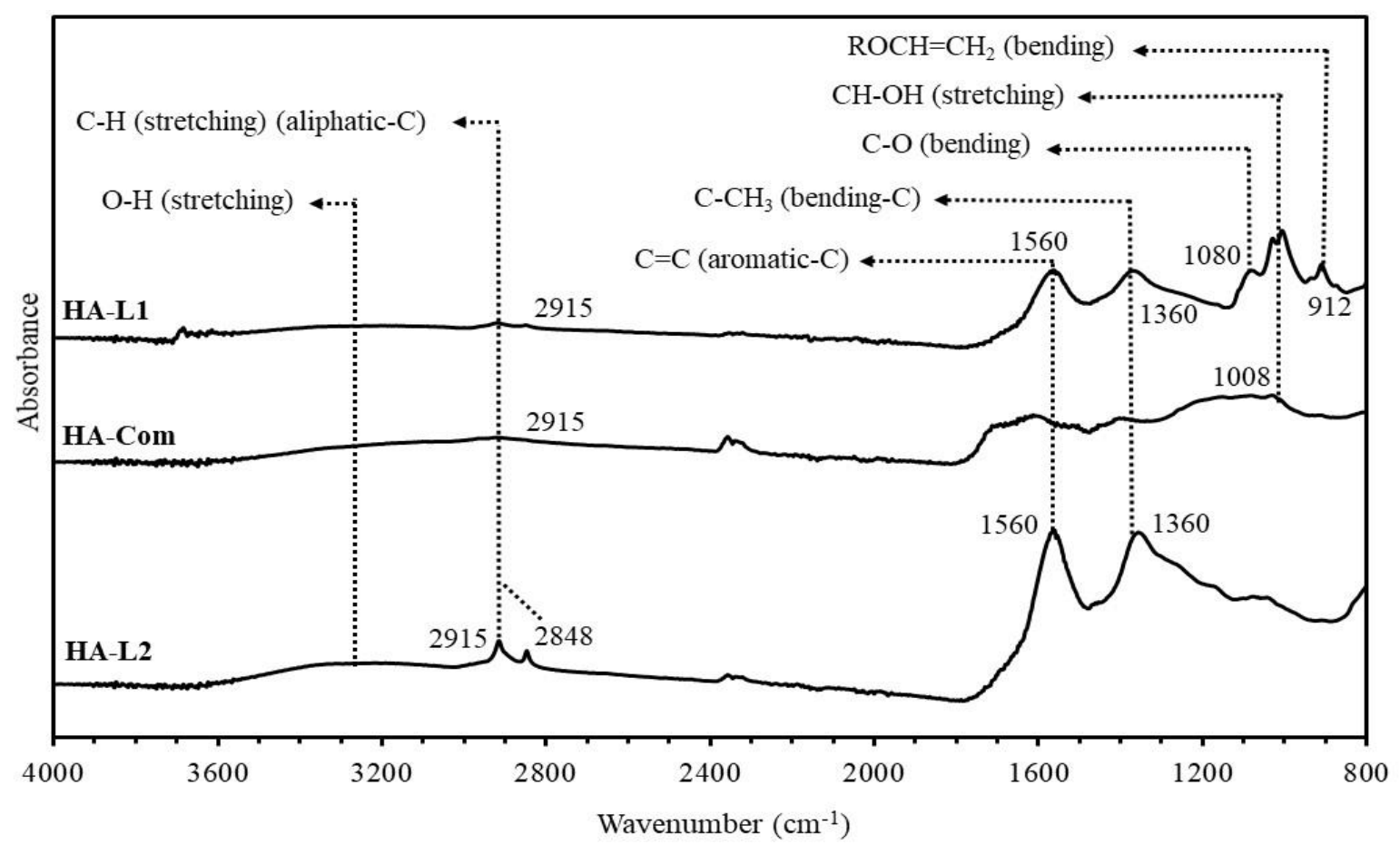

A randomized block statistical design was used with 4 replications in a $3 \times 4+1$ factorial scheme, combining three sources of HA (HA-L1, HA-Com, and HA-L2) with four concentrations of C-HA (5, 10, 25, and $100 \mathrm{mg} \mathrm{L}^{-1}$ ), plus a control treatment representing growth of plants only in nutrient solution. Three plants were grown per pot with a 2.3 L capacity. The plants were first removed from the seedling plugs they were in and, soon after, the substrate adhering to the root was removed. This was done manually, using deionized water, so as not to compromise the root system. After this step, the seedlings were transferred to trays containing $20 \mathrm{~L}$ nutrient solution adapted from Hoagland and Arnon (1950), and allowed to adapt for 21 days in this growth medium, with a gradual increase in the strength of the nutrient solution every 7 days $(25,50$, and 100\%). Following this adaptation phase, eucalyptus seedlings were transferred to the treatments and grown in a nutrient solution with the following nutrient concentrations: $14,196,31,235$, $160,49,68,5,0.8,1,0.20,0.05$, and $0.01 \mathrm{mg} \mathrm{L}^{-1}$ of 
$\mathrm{N}-\mathrm{NH}_{4}^{+}, \mathrm{N}^{-\mathrm{NO}_{3}}{ }_{3}^{-}, \mathrm{P}, \mathrm{K}, \mathrm{Ca}, \mathrm{Mg}, \mathrm{S}, \mathrm{Fe}, \mathrm{B}, \mathrm{Mn}, \mathrm{Zn}, \mathrm{Cu}$, and $\mathrm{Mo}$, respectively. The salts used for formulation of the nutrient solution were derived from analytical grade reagents. After the addition of HA and their concentrations in nutrient solution, the $\mathrm{pH}$ of the growth medium was adjusted to $5.5 \pm 0.2$, with addition of $0.5 \mathrm{~mol} \mathrm{~L}^{-1} \mathrm{KOH}$ or of $0.5 \mathrm{~mol} \mathrm{~L}^{-1} \mathrm{HCl}$ solutions. Aeration was constant and individualized in each pot throughout the experimental period. The growing seedlings were constantly aerated through injection of air directly in the nutrient solution via a system of secondary hoses connected to a main line; the air contained in the main line came from an electric air compressor.

After one day of cultivation, a 30-mL aliquot of nutrient solution was collected from each experimental pot for $\mathrm{pH}$ and electrical conductivity (EC) determination. Plants were cultivated for 20 days, and the nutrient solution was renewed every 10 days. When the solution was exchanged, the HA from different sources and their concentrations were reapplied. In the interval between renewal of the nutrient solution, the volume of each pot was completed daily using deionized water. At the end of the experiment, plants were harvested, washed in distilled water, separated into root and shoot, and, then, dried in a laboratory oven at $60^{\circ}$ for 72 hours, until constant weight, in order to determine shoot and root dry matter. In sequence, shoot and root samples were ground separately and passed through a sieve (1-mm) for determination of total $\mathrm{N}$ content, using Kjeldahl method and sulfuric acid to digest plant tissue (TEDESCO et al., 1995). Contents of $\mathrm{P}, \mathrm{K}, \mathrm{Ca}, \mathrm{B}, \mathrm{Cu}, \mathrm{Fe}$, and $\mathrm{Zn}$ were determined after digestion of biomass in a nitric-perchloric acid solution at the proportion of 4:1 of these acids, respectively (MALAVOLTA et al., 1997). The accumulation of each nutrient was determined in both the root and the shoot using the nutrient concentration in the plant tissue together with its respective dry matter, according to equation 1. The absorption efficiency (UpE) of the nutrients was also calculated based on the index proposed by
Bataglia et al. (1983) (Equation 2).

$$
\mathrm{CN}\left(\mathrm{mg} \mathrm{pot}^{-1}\right)=\mathrm{DM} \times \mathrm{Nu}
$$

in which $\mathrm{CN}$ is the accumulated nutrient content in the plant compartment analyzed $\left(\mathrm{mg} \mathrm{pot}^{-1}\right)$; DM is the dry matter production of the compartment analyzed $\left(\mathrm{g} \mathrm{pot}^{-1}\right)$, and $\mathrm{Nu}$ is the nutrient content in the plant compartment analyzed $\left(\mathrm{mg} \mathrm{kg}^{-1}\right)$.

$$
\mathrm{UpE}\left(\mathrm{mg} \mathrm{g}^{-1}\right)=\mathrm{CNT} / \mathrm{RDM} \quad \text { (Eq. 2) }
$$

in which UpE is the uptake efficiency, CNT is the total accumulated content of the nutrient in the plant $\left(\mathrm{mg} \mathrm{pot}^{-1}\right)$, and RDM is the root dry matter $\left(\mathrm{g} \mathrm{pot}^{-1}\right)$

The data set was subjected to analysis of variance $(p<0.05)$, first testing the factorial against the control treatment. HA sources and concentrations were compared according to the absence or presence of interaction between the factors studied. The mean cluster test of Scott-Knott was used $(p<0.05)$ to differentiate the effect of HA sources on the attributes evaluated. Regarding HA concentrations, a regression models was adjusted to data set aiming at to explain the variations in dry matter production, nutrient acquisition, and nutrient uptake efficiency over C-HA concentrations.

\section{Results and Discussion}

\section{Nutrient solution}

The application of HA increased the $\mathrm{pH}$ and electrical conductivity (EC) of the nutrient solution compared to cultivation in the HA-not treated growth medium. The $\mathrm{pH}$ of the nutrient solution was not affected by the concentrations of HA-Com. However, for the HAs derived from leonardite (HA-L1 and HA-L2), there was an increase in the $\mathrm{pH}$ value with the increase in C-HA concentration (Figure 2). Extraction of HA with strong bases, such as $\mathrm{KOH}$ and $\mathrm{NaOH}$, results in $\mathrm{pH}$ of humic extracts in the alkaline range, which partially explains the nutrient solution $\mathrm{pH}$ increase. HA have the ability of interacting in different ways with metals through ion exchange, chelate formation, organo-metallic complexes, and through adsorption of the metal 
onto the HA matrix, with formation of hydroxides (BOGUTA; SOKOŁOWSKA, 2016). The increase in $\mathrm{pH}$ by some HA sources tested, notably for those derived from leonardite, reduced the availability of nutrients, since, with the increase in $\mathrm{pH}$, the stability of the complex formed between HA and the metal increases (BOGUTA; SOKOLOWSKA, 2016). One day after transferring the eucalyptus plants to the pots with the treatments, a reduction in
$\mathrm{pH}$ of about one unit of the initial value established in the control treatment was noted (Figure 2); however, increase in the concentrations of C-HA was able to buffer the growth medium $\mathrm{pH}$ against sharp changes. This result shows the acidification potential of the eucalyptus root in a medium that is not well buffered for acidity as was noted for the HA-not treated pots.

Figure 2. $\mathrm{pH}$ and electrical conductivity (EC) of the nutrient solution after one day of eucalyptus cultivation as a function humic acid (HA) sources and concentrations. C-HA. HA-L1: HA extracted from Leonardite with $\mathrm{NaOH}$; HA-Com: HA extracted from organic compost with KOH; HA-L2: HA extracted from Leonardite with $\mathrm{KOH}$.

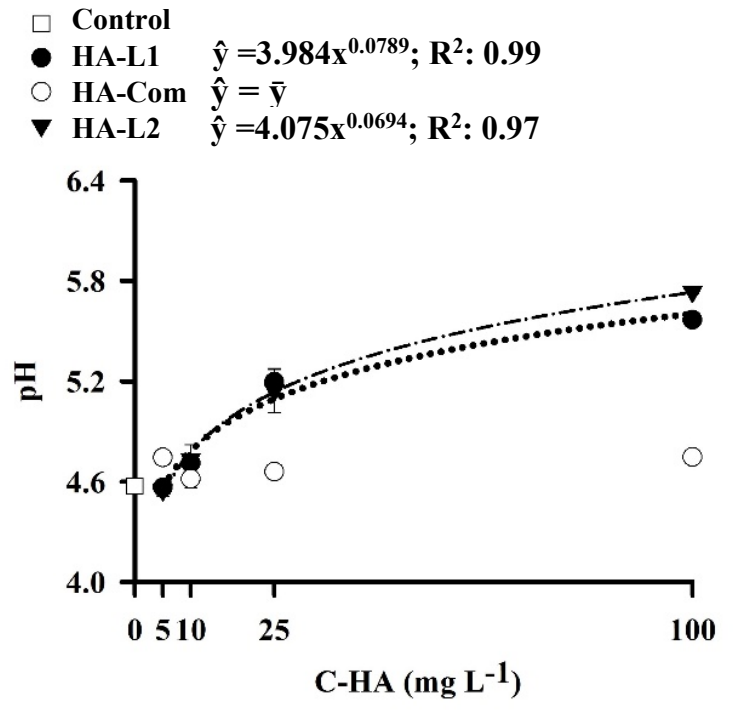

With the increase in the concentrations of C-HA, there was an increase in EC, and the effect for HA-Com on EC was the most pronounced (Figure 2). This increase in EC was related to the imput and changes provoked by the HAs sources as the $\mathrm{C}$-HA concentrations is increased. In some cases, changes in EC to values higher than the optimum limit for eucalyptus decreased seedlings dry matter production (PINHEIRO et al., 2010).

\section{Dry matter production}

Shoot dry matter (SDM) production increased up to the concentration around of $14 \mathrm{mg} \mathrm{L}^{-1} \mathrm{C}-\mathrm{HA}(8.22$

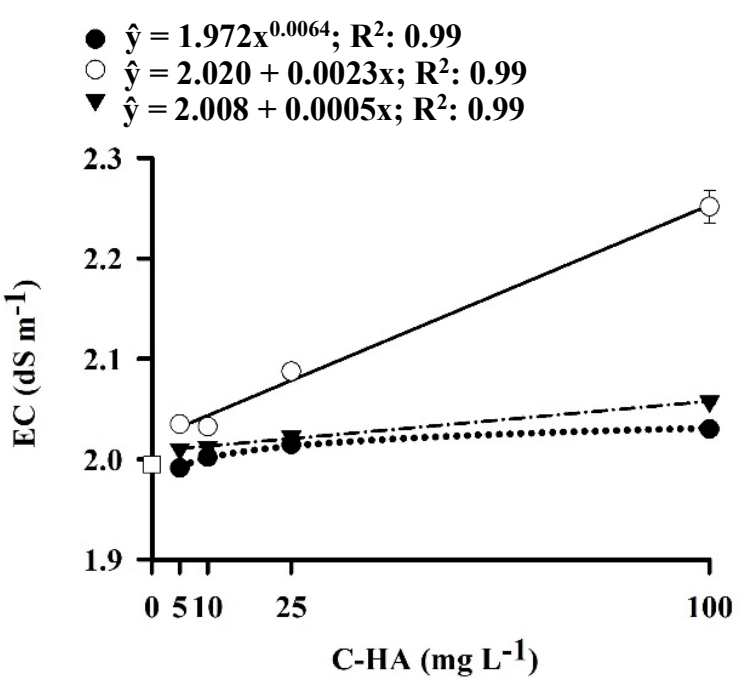

$\mathrm{g} \mathrm{pot}^{-1}$ ) for the HA-L1 and HA-Com, followed by a decline in dry matter for concentrations above the already mentioned (Figure 3). SDM is not affected by C-HA-L2 concentrations, though, at $5 \mathrm{mg} \mathrm{L}^{-1}$ C-HA, SDM produced with HA-L2 is $20 \%$ higher than biomasses reported for the other HA sources. HA derived from compost increased production of root dry matter (RDM) up to the concentration of $55 \mathrm{mg} \mathrm{L}^{-1}$ of C-HA (4.56 $\mathrm{g} \mathrm{pot}^{-1}$ ), a marked different response in relation to the other HA sources, considering the pattern of response of plants to high C-HA concentrations. For the HA-L1 source, a decrease in RDM was verified at concentration of C-HA was increased, and there was no change 
in RDM for the increasing concentrations of HAL2 (Figure 3). The magnitude of the increase in production of SDM depends on the concentration of HA applied (MELO et al., 2015; TAHIR et al.,
2011). Chen and Aviad (1990) reported an increase in growth and nutrient accumulation in plants grown in nutrient solution with humic substances (HS) concentrations ranging from 5 to $300 \mathrm{mg} \mathrm{L}^{-1} \mathrm{HA}$.

Figure 3. Shoot dry matter (SDM), root dry matter (RDM), total dry matter (TDM) and Root:Shoot ratio dry matter (Root:Shoot ratio) of eucalyptus seedlings treated with different humic acid (HA) sources and concentrations. Adjusted regression models for HA-L1: HA extracted from Leonardite with $\mathrm{NaOH}$; HA-Com: HA extracted from organic compost with $\mathrm{KOH}$; HA-L2: HA extracted from Leonardite with KOH; HA-M: mean of the three HA sources, effect isolated of the concentration C-HA.

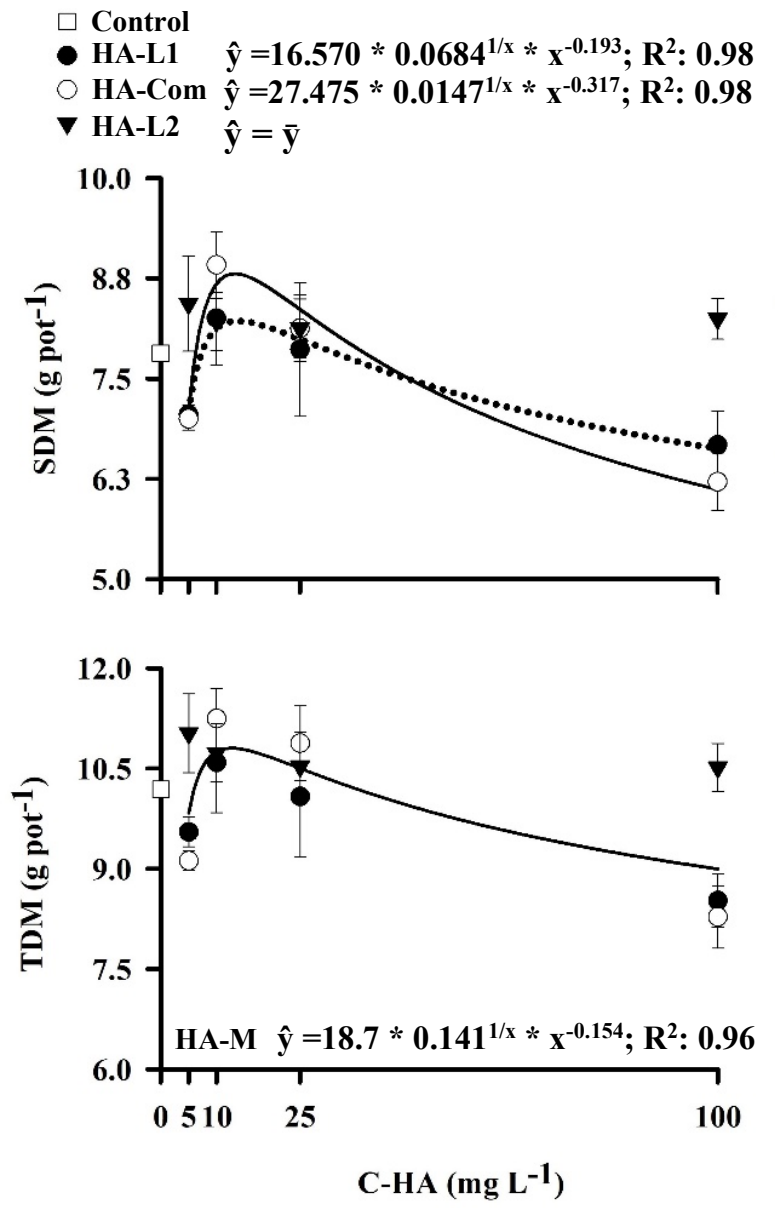

The optimal concentration of HA can vary among sources as a result of differences in the chemical characteristics and bioactive fractions of HS linked to HA matrix used as well as crop response to $\mathrm{HS}$ rates undergoes variation among plant species (AZCONA et al., 2011; ROSE et al., 2014). According to Pinheiro et al. (2010), use of HA concentrations in the range of 0 to

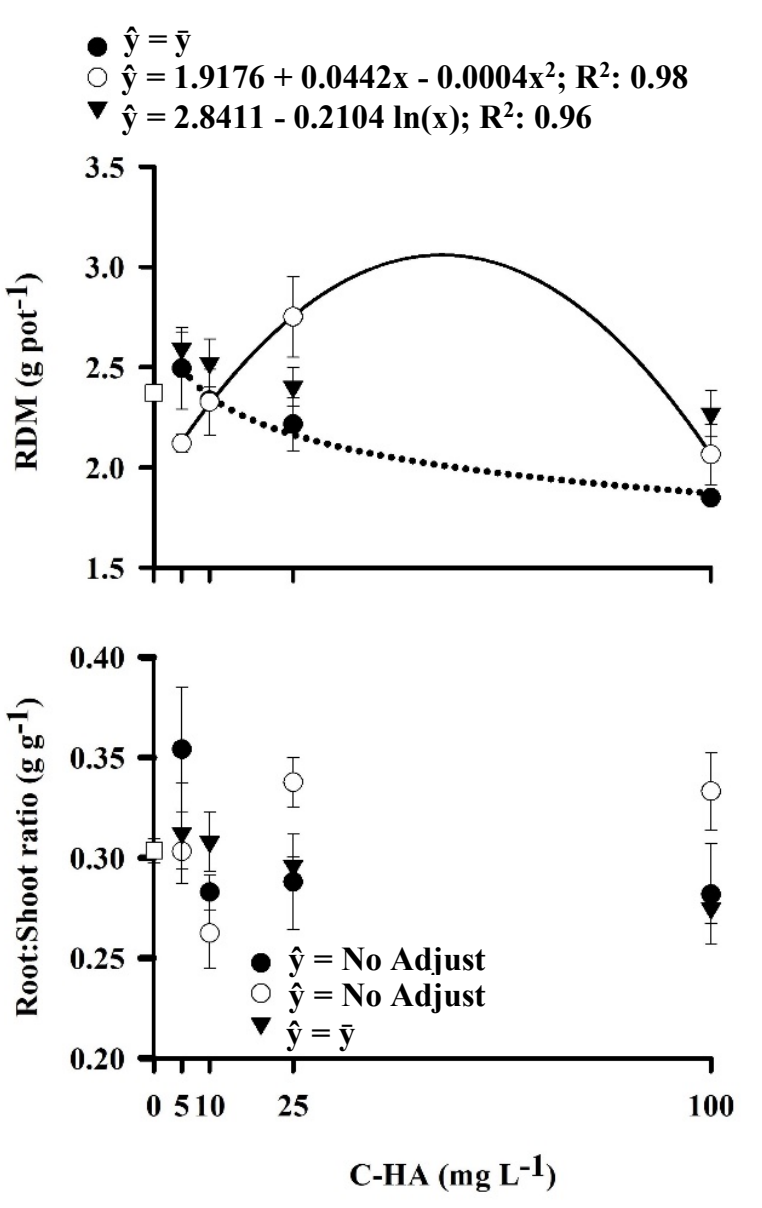

$150 \mathrm{mg} \mathrm{L}^{-1} \mathrm{C}-\mathrm{HA}$ improved growth and nutrient acquisition by eucalyptus seedlings grown in nutrient solution. The greatest seedlings SDM was noted at low concentration of C-HA $\left(3.8 \mathrm{mg} \mathrm{L}^{-1}\right)$, therefore, at $\mathrm{C}$-HA concentrations lower than those found in this work. In this study, low to medium concentrations of C-HA stimulated the growth of eucalyptus shoot. Increase of plant growth rely on 
HA source, considering that HA-Com provided a greater stimulus to plants than the other HA sources. Concentrations of C-HA derived from compost for plentiful eucalyptus root were higher than those required for root biomass production in pots with HA derived from Leonardite.

Total dry matter (TDM) production was influenced only by the concentration of HA, regardless of the source applied, and the maximum TDM production was obtained at the concentration of $12.6 \mathrm{mg} \mathrm{L}^{-1}$ of C-HA, which was $6 \%$ higher than the control TDM; eucalyptus seedling growth decreased at higher concentrations than the aforementioned (Figure 3). For the root:shoot dry matter ratio (Root:Shoot ratio), it was not possible to fit model to relate concentrations of C-HA with Root:Shoot DM ratio (Figure 3). However, at the highest concentration of HA, the source HACom increased the Root:Shoot ratio by $19.7 \%$ as compared to the other HA sources. For the HA-L2 source, there was no influence of the concentration of C-HA applied, and the concentration of $5 \mathrm{mg} \mathrm{L}^{-1}$ of C-HA for HA-L1 promoted a higher Root:Shoot ratio, whereas the concentration of $10 \mathrm{mg} \mathrm{L}^{-1}$ of C-HA decreased the Root:Shoot ratio for HA-Com. The Root:Shoot ratio is plastic, regulated by the source of HA and is dependent on the concentration of HA used. An increase in root growth can lead to reduction in TDM since photoassimilates that could be used in the shoot are mobilized to maximize growth and proliferation of the root system (PINHEIRO et al., 2010). The stimulus in plant root growth is related to the chemical characteristics of HA, which, in counterpart, determine the optimal concentration that promotes greater bioactivity of its humic fragments. HA constituted of more labile fractions have a lower optimal concentration and have a greater effect on plant growth (GARCÍA et al., 2016). Definition of the optimal concentration of HA is crucial since increase in Root:Shoot ratio due to wrong definition of HA rate may hamper eucalyptus growth. In a rich HA-growth media, eucalyptus can translocate photoassimilates and compounds that generate energy for the root, thus compromising shoot development. Thus, it is recommended that concentrations of C-HA not be greater than $15 \mathrm{mg} \mathrm{L}^{-1}$ in the nutrient solution to avoid decreased in eucalyptus growth. For HA-Com, it is important to emphasize that concentrations of $\mathrm{N}$ and $\mathrm{P}$ accumulated in seedlings are greater than amounts determined for the other sources. Thus, extraction and use of HA of composts, among other benefits, can improve $\mathrm{N}$ and $\mathrm{P}$ uptake by plants.

\section{Nutrient accumulation}

The accumulation of $\mathrm{N}$ and $\mathrm{P}$ in the shoot was influenced only by the concentration of C-HA (Figure 4), and maximum accumulation of $\mathrm{N}$ was found for the concentration of $11.7 \mathrm{mg} \mathrm{L}^{-1} \mathrm{C}-\mathrm{HA}$ and maximum accumulation of $\mathrm{P}$ for the concentration of $12.6 \mathrm{mg} \mathrm{L}^{-1} \mathrm{C}$-HA. In shoot, increases of $4.3 \%$ in $\mathrm{N}$ and $14.7 \%$ in $\mathrm{P}$ were verified. There was an increase in $\mathrm{K}$ accumulation in the shoot up to a concentration of $13.5 \mathrm{mg} \mathrm{L}^{-1} \mathrm{C}-\mathrm{HA}$, with later decline as $\mathrm{C}$ as HA-L1 increased. The accumulation of $\mathrm{K}$ in the shoot with the use of HA-Com and HA-L2 sources was not influenced by the concentrations of C-HA tested. The accumulation of $\mathrm{N}, \mathrm{P}$, and $\mathrm{K}$ in the root decreased with over C-HA concentration for the sources HA-L1 and HA-L2 (Figure 4). On contrary, HA-Com increased accumulation of $\mathrm{N}, \mathrm{P}$, and $\mathrm{K}$ up to the concentrations of $15.5,23.1$, and $33.5 \mathrm{mg} \mathrm{L}^{-1}$ C-HA, respectively, followed by a decline of the aforementioned nutrient uptake for concentrations above the optimal levels already cited. The effect of HA on nutrient acquisition by plants may be due to the direct effects on plant growth (CANELLAS; OLIVARES, 2014), or enhanced efficiency of processes involved in the nutrient uptake (JINDO et al., 2016). 
Figure 4. Accumulation of N, P, K and $\mathrm{Ca}$ in shoot and root of eucalyptus seedlings treated with different humic acid (HA) sources and concentrations of C-HA. Adjusted regression models for HA-L1: HA extracted from Leonardite with $\mathrm{NaOH}$; HA-Com: HA extracted from organic compost with $\mathrm{KOH}$; HA-L2: HA extracted from Leonardite with $\mathrm{KOH}$; HA-M: mean of the three HA sources, effect isolated of the concentration C-HA.

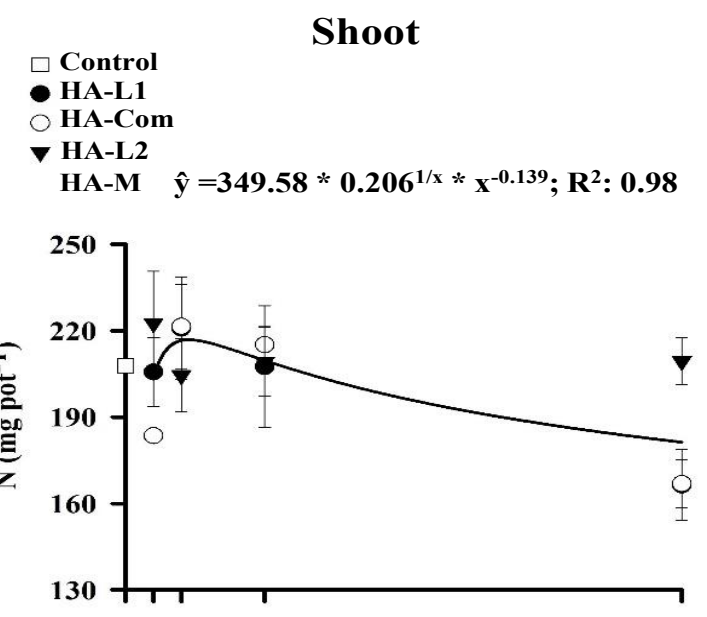

\section{Root}
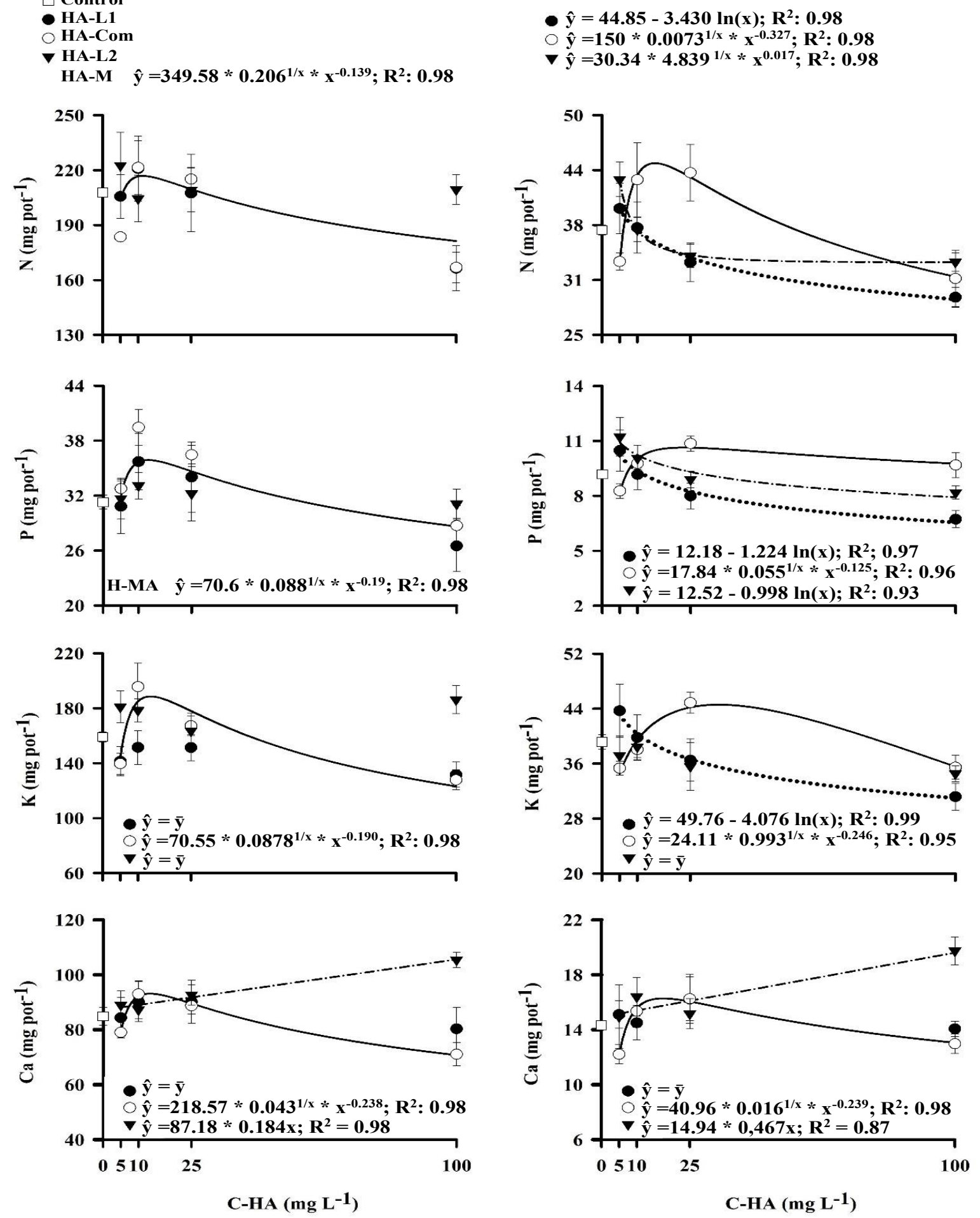
The magnitude of HA bioactivity is regulated by the concentration, chemical composition, and nature of the organic ligands present in the humic matrix (AGUIAR et al., 2009; AZCONA et al., 2011; CANELLAS et al., 2015). HA derived from organic materials may be more bioactive than those derived from mineral sources like lignite, because they contain organic acids, low molecular weight soluble fractions, and hormones produced during composting (ROSE et al., 2014), factors which positively affect root proliferation and plant growth (BALDOTTO, et al., 2016; DOBBSS et al., 2010; MELO et al., 2015). Rose et al. (2014) reported that the beneficial effect on growth of diverse plant species from applications of increasing concentrations of HA is described by quadratic equations, with greater plant growth up to the optimal concentration of HA and decline in growth for concentrations above the threshold limit. Decrease in plant growth treated with HS can be explained by the formation of organo-metallic complexes of high chemical stability, especially with micronutrients, which limit plant growth and, consequently, affect nutrient accumulation in eucalyptus shoot (PINHEIRO et al., 2010). Concentrations of C-HA up to $13.5 \mathrm{mg} \mathrm{L}^{-1}$ favor the accumulation of $\mathrm{N}, \mathrm{P}$, and $\mathrm{K}$ in the shoot of eucalyptus (Figure 4), mainly due to enhance eucalyptus growth than to improved efficiency of plants in uptake and use nutrients at low HA concentrations. Only HA-Com proved to be effective in increasing $\mathrm{N}, \mathrm{P}$, and $\mathrm{K}$ accumulation in the root, probably due to the positive effect of compost-derived HA on root growth.

Calcium accumulation in the shoot increased with HA-Com up to the concentration of $13.6 \mathrm{mg}$ $\mathrm{L}^{-1} \mathrm{C}-\mathrm{HA}$ and in the root up to the concentration of $17.4 \mathrm{mg} \mathrm{L} \mathrm{m}^{-1} \mathrm{C}-\mathrm{HA}$, followed by decline for HA concentrations greater than those considered optimal (Figure 4). C added as HA-L2 increased linearly the $\mathrm{Ca}$ accumulated in the shoot and root for HA concentration up to $100 \mathrm{mg} \mathrm{L}^{-1}$ of C-HA. On average, $\mathrm{Ca}$ increase $39.3 \%$ in the shoot and $46.1 \%$ in the root in plants treated with HA-L2 in comparison to the other HA sources (Figure 4). $\mathrm{Ca}$ together with $\mathrm{P}$ are the nutrient that strongly limit eucalyptus growth (VIERA et al., 2015). The association of $\mathrm{Ca}$ with $\mathrm{HS}$ gives rise to the $\mathrm{Ca}$ Actosol complex, which increased tomato yield and Ca uptake (EKINCI et al., 2015). According to Azcona et al. (2011), with the increase in HA concentration, there was greater accumulation of $\mathrm{Ca}$ in pepper plants which was regulated by to the source of HA applied. In the HA-L2 matrix, there is more aliphatic C (Figure 1) according to the ATR-FTIR spectra. Thus, it could be inferred that structures of aliphatic $\mathrm{C}$ can show high capacity to complex $\mathrm{Ca}$, optimizing acquisition of this nutrient by eucalyptus. The increase in Ca storage in the root may be a strategy to improve cultivation of eucalyptus under conditions in which $\mathrm{Ca}$ supplying to seedlings is sharply restricted. Plentiful availability of Ca could enhance establishment of seedlings and initial development of eucalyptus in the field, given the role played by $\mathrm{Ca}$ in maintaining the permeability of the root cell plasmatic membrane and the uptake of other nutrients, an effect known as Viets (VIETS, 1944). In Brazil, the role played by $\mathrm{Ca}$ on plant nutrition is magnified, taking into account the fact that eucalyptus is commonly grown in fragile soils with low fertility degree and reduced capacity to supply Ca to young plants.

For HA-L1 and HA-Com, an increase was found in $\mathrm{B}$ accumulation in the shoot as concentration of C-HA increased to $11.7 \mathrm{mg} \mathrm{L}^{-1}$ for HA-L1 and 16.4 $\mathrm{mg} \mathrm{L}^{-1}$ for HA-Com, followed by a decline in $\mathrm{B}$ uptake for C-HA beyond the optimal concentration (Figure 5). The same tendency and optimal concentration were observed for $\mathrm{B}$ accumulation in the root for HA-Com, though the HA-L2 C-HA concentrations did not affected $\mathrm{B}$ accumulation in the root. The different concentrations of C-HA did not influence $\mathrm{B}$ accumulation in the shoot when HA-L2 was used; however, in the root, there was an increase in $\mathrm{B}$ accumulation with the increase in C-HA concentration (Figure 5). Application of HA in the nutrient solution increased $\mathrm{B}$ accumulation in 
the eucalyptus root in relation to the control. B has the ability to form complexes with HS (B-Humate), favoring its acquisition by plants (EKINCI et al., 2015). Regarding B accumulation by eucalyptus seedlings, the response to the C-HA concentrations was HA source-dependent. In line with Pinheiro et al. (2010), use of C-HA at the concentration of 18 $\mathrm{mg} \mathrm{L}^{-1}$ increased B accumulate in eucalyptus shoot. Improved accumulation of B by eucalyptus root can increase B in the shoot, which improves B use in metabolic processes and eucalyptus, optimizing its growth. In Brazilian eucalyptus plantations, water stress decrease B soil availability, reducing uptake and B flux to shoot, an stimulus to plant increases its demand for B (RAMOS et al., 2013). Increase in $B$ accumulated by plants due to application of HA can be used in the field as a practice to improve eucalyptus B nutrition, with the use of low HA concentrations.

There was an isolated effect of sources and concentrations of $\mathrm{HA}$ on accumulation of $\mathrm{Cu}$ in shoot (Figure 5). The sources HA-L2 and HACom increased acquisition of $\mathrm{Cu}$ by $12.7 \%$, with maximum accumulation of $\mathrm{Cu}$ for the concentration of $9.8 \mathrm{mg} \mathrm{L}^{-1}$ of $\mathrm{C}-\mathrm{HA}$, followed by a decline in $\mathrm{Cu}$ accumulated in shoot for HA concentrations beyond the optimal level. The increase in the C-HA concentration decreased $\mathrm{Cu}$ accumulation in the root for HA-L1 and HA-L2. Both sources have higher concentration of aromatic groups (aromatic C) than HA derived from compost as shown in the ATR-FTIR spectra (Figure 1). No influence of C-HA concentrations on $\mathrm{Cu}$ accumulation was verified for HA-Com; HA-Com exhibited greater accumulation of $\mathrm{Cu}$ at the concentration of 25 and $100 \mathrm{mg} \mathrm{L}^{-1}$ of C-HA. With the application of the concentrations of
25 and $100 \mathrm{mg} \mathrm{L}^{-1}$ of C-HA for the HA-Com source (Figure 5), 0.02 and $0.07 \mathrm{mg} \mathrm{L}^{-1}$ of $\mathrm{Cu}$ were added to the nutrient solution, showing the potential of this source in supplying $\mathrm{Cu}$ to eucalyptus. Diverse factors determine the formation of organo-metallic complexes (OMCs). Capacity of these complexes in supplying nutrients to plants depends on the bond strength between ions and organic ligands present in the HS, maximum capacity of metal complexation by ligands, nutrient solution $\mathrm{pH}$, ionic strength of the growth medium, cations that compete for the metal complexed in humic sites, and organic ligand concentration in the humic fractions that are effectively able to mobilize cations in the chelated form (IGLESIAS et al., 2003).

HA has high affinity with $\mathrm{Cu}$, forming highly stable covalent type bonds and complexes less prone to be cleaved and to supply $\mathrm{Cu}$ to seedlings (XU et al., 2016). The chemical stability of the $\mathrm{Cu}$-complex formed is controlled by the presence of phenolic and carboxylic groups in the HA matrix (XU et al., 2016). Thus, eucalyptus growth depends on the ability of OMC to release $\mathrm{Cu}$ to eucalyptus plants (PINHEIRO et al., 2010). $\mathrm{Cu}$ has high affinity for HA, and the increase in the HA concentration applied decrease $\mathrm{Cu}$ acquisition and, consequently, plant growth; however, depending on the HA chemical composition, the type of HA used can become a source of $\mathrm{Cu}$ for the plants, as observed for HA-Com (Figure 5). In future trials, it is necessary to check if the $\mathrm{Cu}$-humic complex supplied by the compost is responsible for the enhanced acquisition of $\mathrm{Cu}$ by eucalyptus seedlings or if the effect of greater uptake is associated with greater supply of $\mathrm{Cu}$, which is more concentrated in the compost than in the leonardite-derived HAs. 
Figure 5. Accumulation of $\mathrm{B}, \mathrm{Cu}, \mathrm{Fe}$ and $\mathrm{Zn}$ in shoot and root of eucalyptus seedlings treated with different humic acid (HA) sources and concentrations of C-HA. Adjusted regression models for HA-L1: HA extracted from Leonardite with $\mathrm{NaOH}$; HA-Com: HA extracted from organic compost with KOH; HA-L2: HA extracted from Leonardite with $\mathrm{KOH}$; HA-M: mean of the three HA sources, effect isolated of the concentration C-HA.

\section{Shoot}
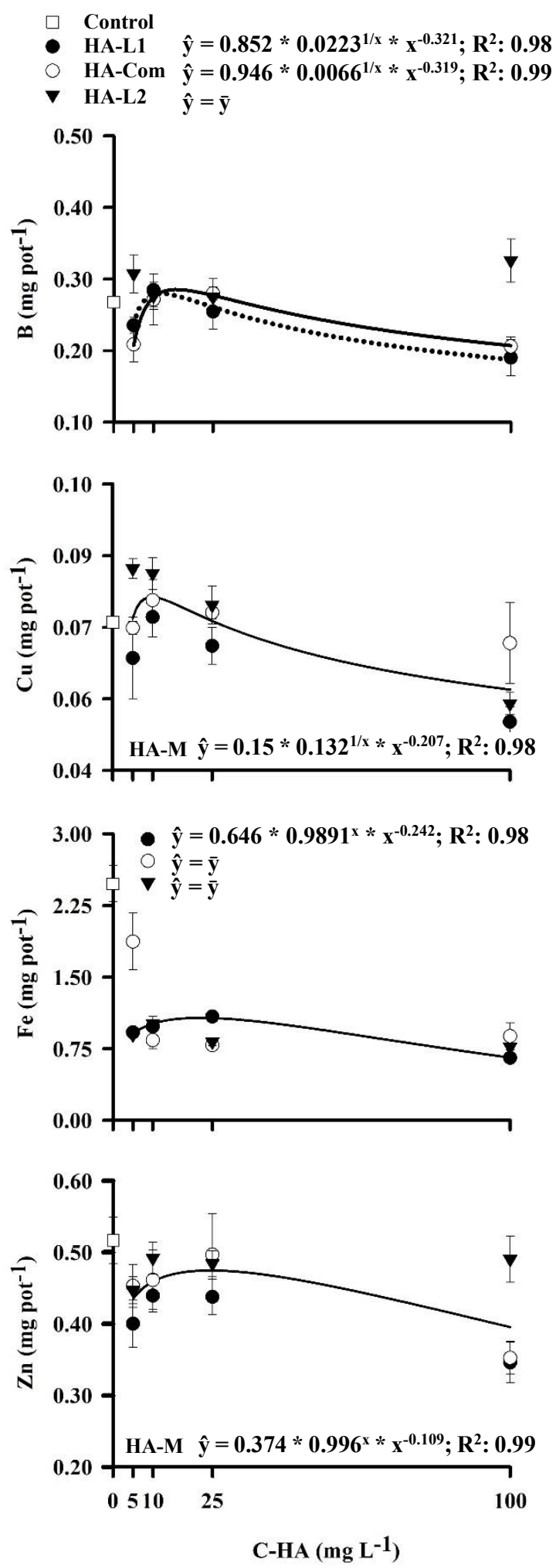

Root
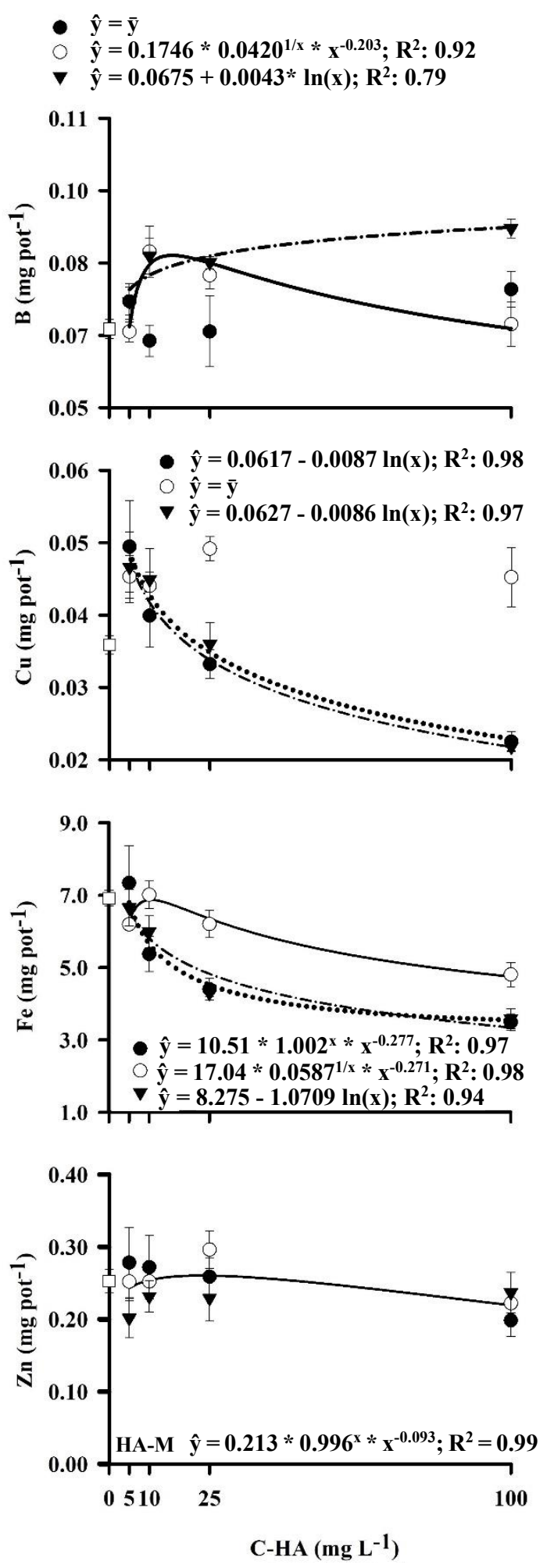
The application of HA restricted Fe supply to eucalyptus, reducing $\mathrm{Fe}$ accumulation by $61.6 \%$ in the shoot and $21.3 \%$ by the root in relation to the uptake by plants grown without HA application (Figure 5). At the concentration of $5 \mathrm{mg} \mathrm{L}^{-1} \mathrm{C}-\mathrm{HA}$, the $\mathrm{HA}-\mathrm{Com}$ increased $\mathrm{Fe}$ acquisition in relation to the other sources, but with a decline of $24.4 \%$ in relation to the control. The accumulation of $\mathrm{Fe}$ in the root increased at the concentration of $10.7 \mathrm{mg} \mathrm{L}^{-1} \mathrm{C}-\mathrm{HA}$ for the source HA-Com; however, for HA-L1 and HA-L2, with an increase in the HA concentration, a reduction in $\mathrm{Fe}$ accumulation in the root was noted (Figure 5). The stability of the complexes formed between organic molecules and the Fe determine if the OMC will act as a source or drain of the nutrient to plants. Humic compounds with fragments of lower molecular weight and OMCs with lower chemical stability increase Fe acquisition by plants (COLOMBO et al., 2014). According to Tomasi et al. (2014), in cucumber plants treated with humic fractions extracted with water, Fe acquisition was increased, improving translocation of Fe from the root to leaves. However, complexes formed between Fe and HA may have high chemical stability, mainly because most $\mathrm{Fe}$ is found in the trivalent form (NUZZO et al., 2013), which can drastically reduce its acquisition by plants. In this study, probably, the high stability of complexes formed between HA and $\mathrm{Fe}$ reduced acquisition of $\mathrm{Fe}$ in the eucalyptus shoot and limited translocation of Fe from the root to the shoot. Therefore, in nutrient solutions, it is reasonable to suppose that the $\mathrm{Fe}$ concentration in the nutrient solution should be increased, especially when offer of organic ligands is abundant in highHA treated growth media.

The application ofHAdecreased $\mathrm{Zn}$ accumulation in the shoot by $14.5 \%$ in relation to cultivation of eucalyptus only in nutrient solution (Figure 5). There was an isolated effect of HA sources and concentrations in $\mathrm{Zn}$ accumulation in the shoot and root, and the concentration of $24 \mathrm{mg} \mathrm{L}^{-1} \mathrm{C}-\mathrm{HA}$ resulted in greater accumulation of $\mathrm{Zn}$ in the shoot, and $23 \mathrm{mg} \mathrm{L}^{-1}$ of C-HA resulted in greater $\mathrm{Zn}$ accumulation in the root (Figure 5). The source HA$\mathrm{L} 2$ increased the accumulation of $\mathrm{Zn}$ in the shoot by $13 \%$; however, it decreased the accumulation in the root by $11.4 \%$ in relation to the other HA sources studied (Figure 5). Büyükkeskin et al. (2015), upon cultivating green beans in nutrient solution, reported an increase in $\mathrm{Zn}$ accumulation from the application of $10 \mathrm{~mL} \mathrm{~L}^{-1} \mathrm{HA}$ for plants under $\mathrm{Al}$ stress conditions. Rose et al. (2014) observed that, in hydroponic studies, there is, initially, a growing increase in bioavailability of metals, such as Zn, from the application of HA. However, with an increase in HA concentration, high stability OMCs are formed, which reduce the bioavailability of $\mathrm{Zn}$. The increase in stability of OMCs between HA and $\mathrm{Zn}$ is favored by low $\mathrm{Zn}$ concentrations in the cultivation medium and an increase in the degree of humification of the $\mathrm{HA}$; this may come to a point that the stability is so large that cleavage of OMCs is difficult (BOGUTA; SOKOLOWSKA, 2016), restricting Zn uptake by plants. The HA concentration was more effective in increasing $\mathrm{Zn}$ accumulation by eucalyptus than the source of HA applied. Concentrations of around 24 $\mathrm{mg} \mathrm{L}^{-1}$ of $\mathrm{C}$ as HA extracted from compost were effective in promoting greater $\mathrm{Zn}$ accumulation by eucalyptus seedlings in comparison to control pots. Above the HA optimal concentration, increase in the supply of C-HA in nutrient solution may have led to the formation of high stability complexes, which, probably, affected $\mathrm{Zn}$ acquisition by plants.

\section{Efficiency of nutrient uptake}

There was no influence of sources and concentrations of HA on uptake efficiency (UpE) of $\mathrm{N}$ and $\mathrm{K}$ (Figure 6), but changes in $\mathrm{P}$ and $\mathrm{UpE}$ were verified for the factors tested. The source HA$\mathrm{L} 2$ reduced the $\mathrm{UpE}$ of $\mathrm{P}$ by $9.1 \%$ compared to the other HA sources (Figure 6). There was a decline in $\mathrm{Ca}$ uptake efficiency with the increase in C-HA concentration. The HS are able to optimize nutrient 
acquisition by plants, whether by stimulation of cell transporters that increase P uptake (JINDO et al., 2016), or stimulation of plasmatic membrane $\mathrm{H}^{+}$ATPase, generating an electrochemical difference of protons between it and the outside medium which increases nutrient uptake (CANELLAS et al., 2015), including $\mathrm{N}$ acquisition by plants (TAVARES et al., 2017). HS acts stimulating the number of physiologically active roots (RIMA et al., 2011) and increase root growth (MELO et al., 2015; ROSE et al., 2014), Such effects depends on the HA concentration and properties (AGUIAR et al., 2009). Lability of the compounds present in the HA also regulates this effect, since sources with more labile compounds have a greater effect at lower HA concentrations (GARCÍA et al., 2016). Increased growth and accumulation of $\mathrm{N}, \mathrm{P}, \mathrm{K}$, and $\mathrm{Ca}$ (Figure 4) at optimal concentrations of C-HA were due mainly to greater eucalyptus biomass production (Figure 3), and slightly influenced by a greater nutrient acquisition or UpE (Figure 6). Thus, the definition of adequate C-HA concentration for crops should focus on mainly in increasing seedlings growth instead to stimulate nutrient acquisition.

There was a decline in the $\mathrm{UpE}$ of $\mathrm{B}, \mathrm{Fe}$, and $\mathrm{Zn}$ with the increase in the concentration of HA, regardless of the source used (Figure 6). Application of HA, regardless of the source and concentration, reduced $\mathrm{UpE}$ of $\mathrm{Fe}$ by $30.5 \%$ in relation to the treatment without HA addition (Figure 6). For $\mathrm{Cu}$, only the influence of the source of HA was noted, and HA-Com increased the UpE of $\mathrm{Cu}$ by $14.8 \%$ in relation to the other HA sources studied (Figure 6), possibly because the compost-derived
HA had the highest $\mathrm{Cu}$ concentration (Table 1). It is recognized that complexation between HA and metals, forming high covalent energy bonds, reduces the availability of some micronutrients, which compromises their acquisition, decreasing UpE, and this may come to the threshold levels which induces the metal nutritional deficiencies in cultivated plants (MOREIRA et al., 2016). According to Elena et al. (2009), the application of HA extracted from Leonardite stimulated the activity of $\mathrm{Fe}$ (III) chelate-reductase, increasing the efficiency of Fe acquisition, as well as favoring greater accumulation of the nutrient in the plant tissue. The humic fractions extracted with water were more effective in increasing the utilization of Fe (TOMASI et al., 2014), which, according to the authors, occurs due to the formation of less stable complexes between humic molecules and Fe. However, in the present study, a sharp decrease in $\mathrm{UpE}$ of Fe with the application of HA was observed; since the HA used. Considering that in this work HA was extracted with solutions highly concentrated in $\mathrm{K}$ or $\mathrm{Na}$, this could be one reason why pattern of $\mathrm{Fe}$ acquisition was contrary to that observed for humic fractions extracted with water. The increase in the concentration of C-HA reduced acquisition of micronutrients by eucalyptus, compromising use efficiency of them, especially Fe. However, this reduction is more pronounced at high concentrations of C as HA (100 $\mathrm{mg} \mathrm{L}^{-1}$ of C-HA). Nevertheless, low concentrations of $\mathrm{C}$-HA promoted greater growth of the eucalyptus seedlings compared to not HAtreated plants, even without increasing the UpE of metallic micronutrients. 
Figure 6. Nutrient efficiency uptake of N, P, K, Ca, B, Cu, Fe e $\mathrm{Zn}$ of eucalyptus seedlings treated with different humic acid (HA) sources and concentrations of C-HA. Adjusted regression models for HA-L1: HA extracted from Leonardite with $\mathrm{NaOH}$; HA-Com: HA extracted from organic compost with KOH; HA-L2: HA extracted from Leonardite with $\mathrm{KOH}$; HA-M: mean of the three HA sources, effect isolated of the concentration C-HA.
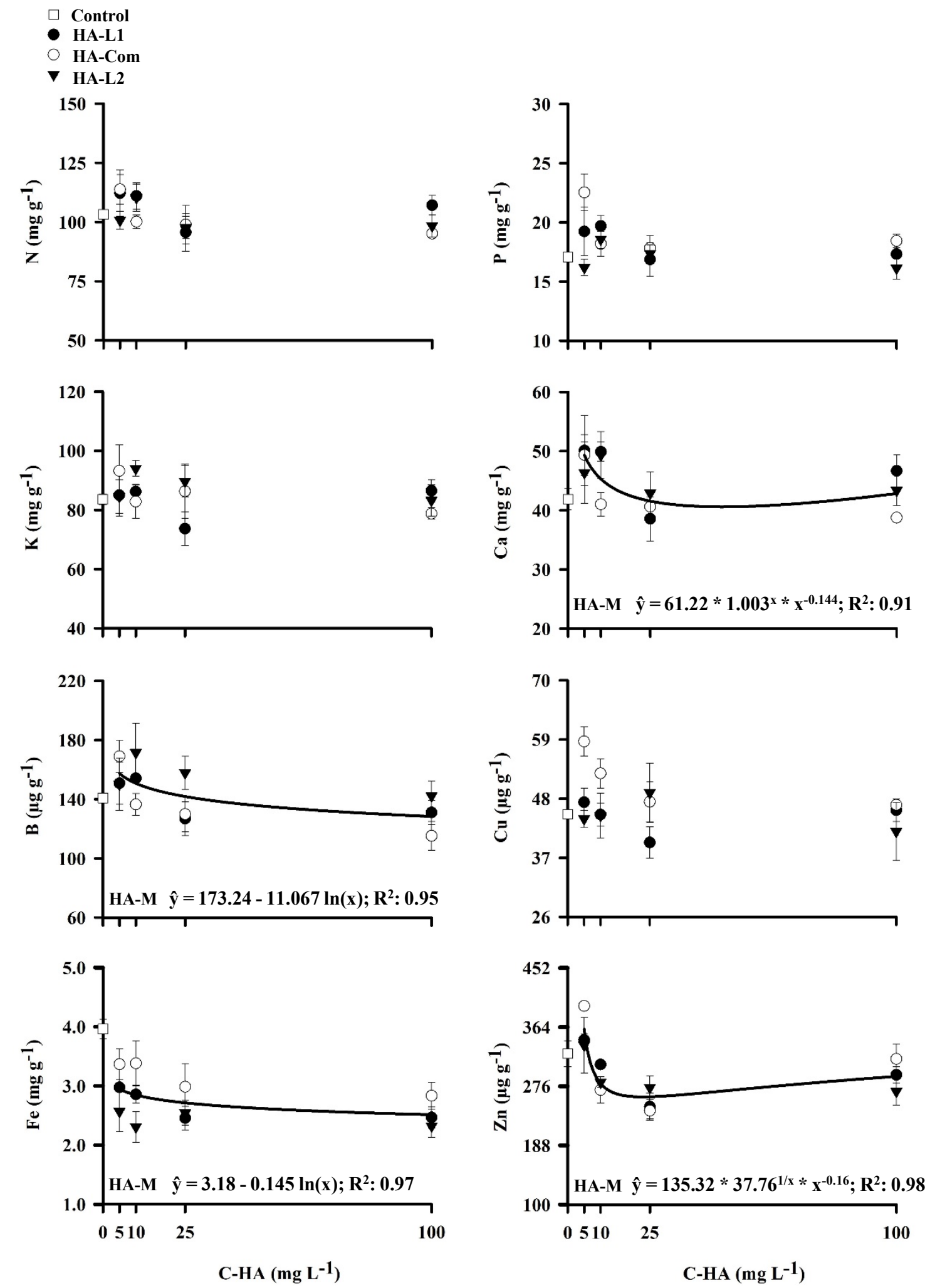


\section{Conclusions}

Low concentrations of humic acid (HA), around $14 \mathrm{mg} \mathrm{L}^{-1}$ of C-HA, are necessary to increase eucalyptus shoot dry matter from 6 to $18 \%$. HA extracted from compost ensured greater growth than HAs derived from Leonardite on both shoot and root of eucalyptus seedlings. To optimize root growth, the concentration of the compost-derived $\mathrm{HA}$ is five times greater than the concentration required for optimum seedlings shoot growth.

Regardless of the source and concentration of C-HA used, there is a sharp reduction in the amounts of $\mathrm{Fe}$ accumulated in shoot, reflecting the difficulty of $\mathrm{Fe}$ in translocating from the root to the eucalyptus leaf. As the C-HA concentration is increased, $\mathrm{Cu}$ accumulated in eucalyptus is sharply diminished. Thus, increase in the concentration of HA means more organic ligands in the nutrient solution, and, consequently, a limited supply of Fe and $\mathrm{Cu}$ for eucalyptus seedlings.

The biostimulant effect of HA ensures greater acquisition of nutrients by eucalyptus seedlings, promoting greater growth and production of shoot and root dry matter at low concentrations of C-HA, but the HAs and their concentrations do not ensure optimization of nutrient uptake efficiency by eucalyptus seedlings.

\section{Acknowledgments}

This study was funded by the National Council for Technological and Scientific Development - CNPq provides, grants 461935/2014-7 and 303899/2015-8, Coordination for the Improvement of Higher Level Education Personnel (CAPES-PROEX AUXPE 590/2014) and Minas Gerais Research Foundation (Fapemig). CNPq provide a scholarship to Carlos A. Silva and CAPES, to first author of this study. The funders aforementioned had no role in the study design, data collection and analysis, decision to edit and to publish the manuscript.

\section{References}

AGUIAR, N. O.; CANELLAS, L. P.; DOBBSS, L. B.; ZANDONADI, D. B.; OLIVARES, F. L.; FAÇANHA, A. R. Molecular weight distribution of humic acids and root growth promotion. Revista Brasileira de Ciência do Solo, Viçosa, v. 33, n. 6, p. 1613-1623, 2009.

AZCONA, I.; PASCUAL, I.; AGUIRREOLEA, J.; FUENTES, M.; GARCÍA-MINA, J. M.; SÁNCHEZDÍAZ, M. Growth and development of pepper are affected by humic substances derived from composted sludge. Journal of Plant Nutrition and Soil Science, Weinheim, v. 174, n. 6, p. 916-924, 2011.

BALDOTTO, M. A.; ROCHA, J. E. ANDRADE, F. D. P.; GIÚDICE, M. P. D.; BALDOTTO, L. E. B. The plant stimulant humic acid extracted from organic waste recycled by composting combined with liming and fertilization. Semina: Ciências Agrárias, Londrina, v. 37, n. 6, p. 3955-3964, 2016.

BATAGLIA, O. C.; FURLANI, A. M. C.; TEIXEIRA, P. R.; FURLANI, P. R.; GALLO, J. R. Métodos de análise química de plantas. Campinas: Instituto Agronômico de Campinas, 1983. 48 p. (Boletim técnico, 78).

BILLARD, V.; ETIENNE, P.; JANNIN, L.; GARNICA, M.; CRUZ, F.; GARCIA-MINA, J. M.; YVIN, J. C.; OURRY, A. Two biostimulants derived from algae or humic acid induce similar responses in the mineral content and gene expression of winter oilseed rape (Brassica napus L.). Journal of Plant Growth Regulation, New York, v. 33, v. 2, p. 305-316, 2014.

BOGUTA, P.; SOKOŁOWSKA, Z. Interactions of Zn(II) ions with humic acids isolated from various type of soils. Effect of $\mathrm{pH}, \mathrm{Zn}$ concentrations and humic acids chemical properties. PLoS One, San Francisco v. 11, n. 4, p. 153-626, 2016.

BÜYÜKKESKIN, T.; AKINCI, Ş.; EROĞLU, A. E. Effects of humic acid on root development and nutrient uptake of Vicia faba L. (broad bean) seedlings grown under aluminum toxicity. Communications in Soil Science and Plant Analysis, Philadelphia, v. 46, n. 3, p. 277-292, 2015.

CANELlaS, L. P.; OLIVARES, F. L. Physiological responses to humic substances as plant growth promoter. Chemical and Biological Technologies in Agriculture, Heidelberg, v. 1, n. 1, p. 1-3, 2014.

CANELlaS, L. P.; OLIVARES, F. L.; AGUIAR, N. O.; JONES, D. L.; NEBBIOSO, A.; MAZZEI, P.; PICCOLO, A. Humic and fulvic acids as biostimulants in horticulture. Scientia Horticulturae, Amsterdam, v. 196, n. 1 , p. $15-27,2015$. 
CHEN, Y.; AVIAD, T. Effects of humic substances on plant growth, In: MACCARTHY, P.; CLAPP, C. E.; MALCOLM, R. L.; BLOOM, P. R. Humic substances in soil and crop sciences: selected readings. Chicago: International Humic Substances Society, 1990. p. 161186.

COLOMBO, C.; PALUMBO, G.; HE, J. Z.; PINTON, R.; CESCO, S. Review on iron availability in soil: interaction of Fe minerals, plants, and microbes. Journal of Soils and Sediments, Heidelberg, v. 14, n. 3, p. 538548, 2014.

DOBBSS, L. B.; CANELlAS, L. P.; OLIVARES, F. L.; AGUIAR, N. O.; PERES, L. E. P.; AZEVEDO, M.; SPACCINI, R.; PICCOLO, A.; FAÇANHA, A. R. Bioactivity of chemically transformed humic matter from vermicompost on plant root growth. Journal of Agricultural and Food Chemistry, New York, v. 58, n. 6, p. 3681-3688, 2010.

EKINCI, M.; ESRINGÜ, A.; DURSUN, A.; YILDIRIM, E.; TURAN, M.; KARAMAN, M. R.; ARJUMEND, T. Growth, yield, and calcium and boron uptake of tomato (Lycopersicon esculentum L.) and cucumber (Cucumis sativus L.) as affected by calcium and boron humate application in greenhouse conditions. Turkish Journal of Agriculture and Forestry, Ankara, v. 39, n. 5, p. 613-632, 2015.

ELENA, A.; DIANE, L.; EVA, B.; MARTA, F.; ROBERTO, B.; ZAMARREÑO, A. M.; GARCÍAMINA, J. M. The root application of a purified leonardite humic acid modifies the transcriptional regulation of the main physiological root responses to Fe deficiency in Fe-sufficient cucumber plants. Plant Physiology and Biochemistry, Paris, v. 47, n. 3, p. 215-223, 2009.

GARCÍA, A. C.; DE SOUZA, L. G. A.; PEREIRA, M. G.; CASTRO, R. N.; GARCÍA-MINA, J. M.; ZONTA, E.; LISBOA, F. J. G.; BERBARA, R. L. L. Structureproperty-function relationship in humic substances to explain the biological activity in plants. Scientific Reports, London, v. 6, n. 20798, p. 1-10, 2016.

HIGASHIKAWA, F. S.; SILVA, C. A.; BETTIOL, W. Chemical and physical properties of organic residues. Revista Brasileira de Ciência do Solo, Viçosa, v. 34, n. 5, p. 1742-1752, 2010.

HOAGLAND, D. R; ARNON, D. I. The water culture method for growing plants without soil. Berkeley: University of California Agricultural Experiment Station, 1950. 32 p. (Circular, 347).

IGLESIAS, A.; LÓPEZ, R.; FIOL, S.; ANTELO, J. M.; ARCE, F. Analysis of copper and calcium-fulvic acid complexation and competition effects. Water Research,
Oxford, v. 37, n. 15, p. 3749-3755, 2003.

JINDO, K.; SOARES, T. S.; PERES, L. E. P.; AZEVEDO, I. G.; AGUIAR, N. O.; MAZZEI, P.; SPACCINI, R.; PICCOLO, A.; OLIVARES, F. L.; CANELLAS, L. P. Phosphorus speciation and high-affinity transporters are influenced by humic substances. Journal of Plant Nutrition and Soil Science, Weinheim, v. 179, n. 2, p. 206-214, 2016.

LYONS, G.; GENC, Y. Commercial humates in agriculture: real substance or smoke and mirrors? Agronomy, Basel, v. 6, n. 4, p. 1-8, 2016.

MALAVOLTA, E.; VITTI, G. C.; OLIVEIRA, S. A. Avaliação do estado nutricional de plantas: princípios e aplicações. 2. ed. Piracicaba: Potafos, 1997. 308 p.

MARTINEZ-BALMORI, D.; SPACCINI, R.; AGUIAR, N.O.; NOVOTNY,E.H.; OLIVARES, F. L.; CANELLAS, L. P. Molecular characteristics of humic acids isolated from vermicomposts and their relationship to bioactivity. Journal of Agricultural and Food Chemistry, New York, v. 62, n. 47, p. 11.412-11.419, 2014.

MELO, R. O.; BALDOTTO, M. A.; BALDOTTO, L. E. B. Corn initial vigor in response to humic acids from bovine manure and poultry litter. Semina: Ciências Agrárias, Londrina, v. 36, n. 3, p. 1863-1874, 2015.

MOREIRA, S. G.; PROCHNOW, L. I.; KIEHL, J. C.; PAULETTI, V.; MARTIN-NETO, L. Chemical forms in soil and availability of manganese and zinc to soybean in soil under different tillage systems. Soil and Tillage Research, Amsterdam, v. 163, n. 1, p. 41-53, 2016.

NARDI, S.; PIZZEGHELLO, D.; SCHIAVON, M.; ERTANI, A. Plant biostimulants: physiological responses induced by protein hydrolyzed-based products and humic substances in plant metabolism. Scientia Agricola, Piracicaba, v. 73, n. 1, p. 18-23, 2016.

NUZZO, A.; SÁNCHEZ, A.; FONTAINE, B.; PICCOLO, A. Conformational changes of dissolved humic and fulvic superstructures with progressive iron complexation. Journal of Geochemical Exploration, Amsterdam, v. 129, n. 1, p. 1-5, 2013.

PICCOLO, A. The supramolecular structure of humic substances. Soil Science, Philadelphia, v. 166, n. 11, p. 810-832, 2001.

PINHEIRO, G. L.; SILVA, C. A.; FURTINI NETO, A. E. Crescimento e nutrição de clone de eucalipto em resposta à aplicação de concentrações de C-ácido húmico. Revista Brasileira de Ciência do Solo, Viçosa, v. 34, n. 4, p. 1217-1229, 2010.

RAMOS, S. J.; FAQUIN, V.; ÁVILA, F. W.; FERREIRA, R. M. A.; ARAÚJO, J. L. Biomass production, B 
accumulation and $\mathrm{Ca} / \mathrm{B}$ ratio in Eucalyptus under various conditions of water availability and $\mathrm{B}$ doses. Cerne, Lavras, v. 19, n. 2, p. 289-295, 2013.

RIMA, J. A. H.; MARTIM, S. A.; DOBBSS, L. B.; EVARISTO, J. A. M.; RETAMAL, C. A.; FAÇANHA, A. R.; CANELlAS, L. P. Adição de ácido cítrico potencializa a ação de ácidos húmicos e altera o perfil protéico da membrana plasmática em raízes de milho. Ciência Rural, Santa Maria, v. 41, n. 4, p. 614-620, 2011.

ROSE, M. T.; PATTI, A. F.; LITTLE, K. R.; BROWN, A. L.; JACKSON, W. R.; CAVAGNARO, T. R. A Metaanalysis and review of plant-growth response to humic substances. Advances in Agronomy, San Diego, v. 124, n. 1, p. 38-89, 2014.

SILVA, C. A. Uso de resíduos orgânicos na agricultura. In: SILVA, L. S.; CANELlAS, L. P.; CAMARGO, O. Fundamentos da matéria orgânica do solo - ecossistemas tropicais e subtropicais. 2. ed. Porto Alegre: Metrópole, 2008. p. 597-621.

STEVENSON, F. J. Humus chemistry: genesis, composition, reaction. 2. ed. New York: John Wiley \& Sons, 1994. $496 \mathrm{p}$.

SWIFT, R. S. Organic matter characterization. In: SPARKS, D. L.; PAGE, A. L.; HELMKE, P. A.; LOEPPERT, R. H.; SOLTANPOUR, P. N.; TABATABAI, M. A.; JOHNSTON, C. T.; SUMMER, M. E. Methods of soil analysis part 3: chemical methods. Madison: Soil Science Society American Journal, 1996. p. 1011-1020.

TAHIR, M. M.; KHURSHID, M.; KHAN, M. Z.; ABBASI, M. K.; KAZMI, M. H. Lignite-derived humic acid effect on growth of wheat plants in different soils. Pedosphere, Beijing, v. 21, n. 1. p. 124-131, 2011.
TAVARES, O. C. H.; SANTOS, L. A.; FERREIRA, L. M.; SPERANDIO, M. V. L.; ROCHA, J. G.; GARCÍA, A. C.; DOBBSS, L. B.; BERBARA, R. L. L.; SOUZA, S. R.; FERNANDES, M. S. Humic acid differentially improves nitrate kinetics under low- and high-affinity systems and alters the expression of plasma membrane $\mathrm{H}+$-ATPases and nitrate transporters in rice: Humic acid alters nitrate uptake kinetics, PM H + -ATPases and NRT expression. Annals of Applied Biology, Hoboken, v. 170, n. 1, p. 89-103, 2017.

TEDESCO, M. J.; GIANLELLO, C.; BISSANI, C. A.; BOHNEN, H.; VOLKWEISS, S. J. Análise de solo, plantas e outros materiais. 2. ed. Porto Alegre: UFRGS/ Departamento de Solos, 1995. 174 p. (Boletim técnico, 5).

TOMASI, N.; MIMMO, T.; TERZANO, R.; ALFELD, M.; JANSSENS, K.; ZANIN, L.; PINTON, R.; VARANINI, Z;; CESCO, S. Nutrient accumulation in leaves of Fe-deficient cucumber plants treated with natural Fe complexes. Biology and Fertility of Soils, New York, v. 50, n. 6, p. 973-982, 2014.

VIERA, M.; SCHUMACHER, M. V.; TRUBY, P.; ARAÚJO, E. F. Implicações nutricionais com base em diferentes intensidades de colheita da biomassa de Eucalyptus urophylla x Eucalyptus globulus. Ciência Rural, Santa Maria, v. 45, n. 3, p. 432-439, 2015.

VIETS, F. G. Calcium and other polyvalent cations as accelerators of ion accumulation by excised barley roots. Plant Physiology, Bethesda, v. 19, n. 3, p. 466-480, 1944.

XU, J.; TAN, W.; XIONG, J.; WANG, M.; FANG, L.; KOOPAL, L. K. Copper binding to soil fulvic and humic acids: NICA-Donnan modeling and conditional affinity spectra. Journal of Colloid and Interface Science, San Diego, v. 473, n. 1, p. 141-151, 2016. 
